Number 5

\title{
TEH CANG SALAK : TEH DARI LIMBAH KULIT SALAK DAN KAYU SECANG YANG BERPOTENSI UNTUK PENCEGAHAN DAN PENGOBATAN PENYAKIT DEGENERATIF
}

\author{
I Wayan Karta ${ }^{1},{ }^{2}$ Putu Annand Kurnia Iswari, ${ }^{3}$ Luh Ayu Nanamy Khrisnashanti Eva Susila \\ ${ }^{1}$ Jurusan Analis Kesehatan Poltekkes Kemenkes Denpasar \\ ${ }^{2}$ KIRS 4 Denpasar \\ ${ }^{3}$ Fakultas Kedokteran, Universitas Diponegoro \\ Jl. Sanitasi No.1 Sidakarya, Denpasar \\ Email: iwayankartaganesh@gmail.com
}

\begin{abstract}
:
Background : Salacca peel and secang wood contain secunder metabolite that use for health, so is needed the practice health product like a tea.

Objective: This study aims to treat salacca peel and secang wood waste into herbal tea and analyze the phytochemical content and antioxidant capacity and organoleptic test of the products made.

Methods: Salacca peel waste samples were taken at the salak center in Sibetan Village and secang wood obtained in Tenganan Village, Karangasem. Antioxidant capacity testing was carried out in the Laboratory Service Unit of the Faculty of Agricultural Technology at UNUD, and phytochemical tests at the Health Polytechnic Department of Denpasar. Organoleptic tests were carried out on 20 panelists. Tea is made by mixing secang wood powder which has been mashed with salak skin powder using 3 variations, namely VR1 (1.5 gram: 0.5 gram), VR2 (1gram: 1 gram), VR3 (0.5 gram: 1.5 gram)), then soaked in hot water and analyzed.

Result: The results showed that Cang Salak Tea with variations of VR1, VR2, and VR3 has active phytochemical content of flavonoids, tannins, alkaloids, terpenoids, and phenols. These compounds have the potential for degenerative diseases. Antioxidant capacity in VR1, VR2, and VR3 are 343.88; 183.88, and $92.12 \mathrm{mg} / \mathrm{L}$ GAEAC. The difference in content is caused by the presence of antioxidants in higher secang wood compared to bark. The most preferred color is in VR1, the aroma is on VR3, and it feels on VR2.

Conclusion: The tea has the potential to be developed into an antioxidant drink which is useful for the prevention and control of degenerative diseases. Organoleptic tests showed that Cang Salak tea products with various variations were favored by panelists. Future studies require strength tests of antioxidant activity and in vitro or in vivo testing of Cang Salak tea for degenerative diseases.
\end{abstract}

Keywords: salacca, secang wood, antioxidant, tea, degenerative disease

\section{PENDAHULUAN}

Penyakit degeneratif adalah

penyakit akibat penurunan fungsi organ tubuh. Tubuh mengalami defisiensi produksi enzim dan hormon, imunodefisiensi, peroksida lipid, kerusakan sel (DNA) danpembuluh darah. Secara umum dikatakan bahwa penyakit ini merupakan proses penurunan fungsi organ tubuh yang umumnya terjadi pada usia tua. Penyakit degeneratif disebut juga sebagai penyakit yang mengiringi proses penuaan. Pesatnya perkembangan penyakit tersebut telah mendorong masyarakat luas untuk memahami dampak yang ditimbulkannya. Menurut WHO, hingga

Meditory | ISSN Online : 2549-1520, ISSN Cetak : 2338 - 1159, Vol. 7, No. 1, Juni 2019 
I Wayan Karta, dkk., Teh Cang Salak:Teh dari Limbah Kulit Salak dan Kayu Secang yang Berpotensi Untuk Pencegahan dan Pengobatan Penyakit Degeneratif

akhir tahun 2005 saja penyakit degeneratif telah menyebabkan kematian hampir 17 juta orang di seluruh dunia. Penyakit degeneratif adalah istilah medis untuk menjelaskan suatu penyakit yang muncul akibat proses kemunduran fungsi sel tubuh dari keadaan normal menjadi lebih buruk. Ada sekitar 50 penyakit degeneratif. Penyakit yang masuk dalam kelompok ini antara lain kanker, diabetes melitus, stroke, jantung koroner, kardiovaskular, obesitas, dislipidemia dan sebagainya. Dari berbagai hasil penelitian modern diketahui bahwa munculnya penyakit degeneratif mempunyai kaitan cukup kuat dengan bertambahnya proses penuaan usia seseorang. Meskipun faktor keturunan juga berperan cukup besar.

Pergesaran pola hidup termasuk pola makan menyebabkan ketidakseimbangan antara senyawa antioksidan dan prooksidan dalam tubuh. Ketidakseimbangan tersebut menyebabkan terjadinya stress oksidatif yang berujung pada terjadinya beberapa penyakit seperti diabetes mellitus, atherosclerosis, kanker, cardiovaskuler. Salah satu upaya untuk menekan terjadinya stress oksidatif pada tubuh adalah dengan menyeimbangkan jumlah antioksidan dan prooksidan dalam tubuh dengan cara mengkonsumsi makanan sebagai sumber senyawa bioaktif untuk meningkatkan kapasitas antioksidan plasma. Oleh karena itu, dibutuhkan produk pangan yang memiliki kandungan aktif antioksidan yang berpotensi untuk pencegahan dan penanggulangan penyakit degeneratif. Dalam penelitian ini akan dikembangkan produk berupa teh dari limbah kulit salak dari Agrowisata Salak Desa Sibetan dan kayu secang dari Desa Tenganan Kabupaten Karangasem.

Bentuk produk ini berupa celup bubuk kulit salak yang dicampur dengan serbuk kayu secang dan dikemas. Produk ini akan dikenal sebagai teh Cang Salak. Istilah "Teh" memiliki makna yang cukup luas, tidak hanya berlaku untuk sebutan tanaman Camellia sinensis (pohon teh). Semua jenis minuman dari tanaman apapun yang disajikan dengan cara diseduh bisa disebut sebagai "Teh". Berbagai jenis minuman yang dihasilkan dari daun, kulit, akar, bunga tumbuhan lain selain tanaman teh juga disebut dengan istilah teh. Misalnya adalah teh ginseng, teh

Meditory | ISSN Online : 2549-1520, ISSN Cetak : 2338 - 1159, Vol. 7, No. 1, Juni 2019 
I Wayan Karta, dkk., Teh Cang Salak:Teh dari Limbah Kulit Salak dan Kayu Secang yang Berpotensi Untuk Pencegahan dan Pengobatan Penyakit Degeneratif

bunga melati, teh daun sirsak, teh bunga rosela atau teh krisan ${ }^{1}$.

Kulit salak di Agro Abian Salak

Desa Sibetan selama ini belum dimanfaatkan, padahal kulit salak memiliki manfaat untuk kesehatan. Sebagian masyarakat percaya dan pernah mencoba meminum air seduhan kulit salak untuk mengatasi penyakit diabetes. Ekstrak etanol kulit buah salak mengandung metabolit sekunder alkaloid, polifenolat, flavonoid, tanin, kuinon, monoterpen dan seskuiterpen dengan parameter standar simplisia non spesifik berupa kadar air sebesar 13,25\%, kadar abu total sebesar 5,61\% dan kadar abu tidak larut asam sebesar 0,50\% ${ }^{2}$. Kayu secang mengandung asam galat, tanin, resin, resorsin, brazilin, brasilein, d-alfaphellandrene, oscimene, minyak atsri. Ekstrak kayu secang (Caesalpinia sappan L.) hasil penapisan mengandung lima senyawa aktif yang terkait dengan flavonoid baik sebagai antioksidan primer maupun antioksidan sekunder. Telah diketahui ternyata flavonoid yang terdapat dalam ekstrak kayu secang memiliki sejumlah kemampuan yaitu dapat meredam atau menghambat pembentukan radikal bebas hidroksil, anion superoksida, radikal peroksil, radikal alkoksil, singlet oksigen, hidrogen peroksida ${ }^{3}$.

Berdasarkan hal tersebut, maka dalam penelitian ini dibuat produk teh Cang Salak untuk dikembangkan menjadi minuman berantioksidan yang bermanfaat bagi penyakit degeneratif. Sehingga dalam penelitian ini diuji kandungan fitokimia dan kadar antioksidan produk teh Cang Salak serta uji organoleptik untuk melihat kesukaan dari masyarakat dalam hal ini panelis.

\section{METODE}

Jenis penelitian yang dilakukan adalah bersifat deskriptif yaitu untuk mengetahui hasil uji fitokimia, kapasitas antioksidan, dan uji organoleptik dari variasi komposisi teh dari kayu secang dan kulit salak. Data primer berupa uji fitokimia dan uji kapasitas antioksidan pada sampel teh dilakukan dengan cara pengujian di laboratorium. Uji fitokimia alkaloid, flavonoid, terpenoid dan steroid, saponin, fenol, dan tanin dilakukan langsung di laboratorium Kimia Terapan Jurusan Analis Kesehatan, sedangkan kapasitas antioksidan dilakukan di Unit Layanan Laboratorium Fakultas Teknologi Pertanian Universitas Udayana. Pada uji organoleptik diuji mengenai aroma, rasa

Meditory | ISSN Online : 2549-1520, ISSN Cetak : 2338 - 1159, Vol. 7, No. 1, Juni 2019 
I Wayan Karta, dkk., Teh Cang Salak:Teh dari Limbah Kulit Salak dan Kayu Secang yang Berpotensi Untuk Pencegahan dan Pengobatan Penyakit Degeneratif

dan warna pada kulit yang diberikan kepada 20 orang.

Tahapan penelitian dilakukan dalam tiga tahapan yaitu tahap persiapan, tahap pelaksanaan, dan tahap analisis data. Formulasi teh dibuat dengan tiga jenis formulasi yaitu (1) Formulasi VR 1 dibuat dengan mencampurkan serbuk kayu secang sebanyak 1,5 gram dengan 0,5 gram serbuk kulit salak; (2) Formulasi VR2 dibuat dengan mencampurkan serbuk kayu secang sebanyak 1,0 gram dengan 1,0 gram serbuk kulit salak; dan (3) Formulasi VR3 dibuat dengan mencampurkan serbuk kayu secang sebanyak 0,5 gram dengan 1,0 gram serbuk kulit salak. Data yang telah diperoleh dari hasil pemeriksaan laboratorium dan organoleptik diolah secara manual dan dianalisa secara deskriptif dalam bentuk tabel dan narasi dengan kajian pustaka yang relevan.

\section{HASIL DAN PEMBAHASAN}

Hasil Uji Fitokimia dan Kapasitas

Antioksidan

Uji fitokimia dilakukan secara kualitatif menggunakan reagen yang sesuai dan dihasilkan seperti pada Tabel 1.

Tabel 1. Hasil Uji Fitokimia pada Variasi Formulasi "Teh Cang Salak"

\begin{tabular}{lcccccc}
\hline \multirow{2}{*}{ Sampel } & \multicolumn{7}{c}{ Uji Fitokimia } \\
\cline { 2 - 7 } & Flavonoid & Tanin & Alkaloid & Terpenoid & Fenol & Saponin \\
\hline VR1 & + & + & + & + & + & - \\
VR2 & + & + & + & + & + & - \\
VR3 & + & + & + & + & + & - \\
\hline \multicolumn{2}{l}{ Uji kapasitas antioksidan } & & menggunakan spektrofotometer, dan \\
knkan dengan metode DPPH & & & dihasilkan data seperti Tabel 2.
\end{tabular}

Tabel 2. Analisa Kapasitas Antioksidan pada Variasi Formulasi“Teh Cang Salak"

\begin{tabular}{lc}
\hline Sampel & Kapasitas Antioksidan (mg/L GAEAC) \\
\hline VR1 & 343,88 \\
VR2 & 183,88 \\
VR3 & 92,12
\end{tabular}


I Wayan Karta, dkk., Teh Cang Salak:Teh dari Limbah Kulit Salak dan Kayu Secang yang Berpotensi Untuk Pencegahan dan Pengobatan Penyakit Degeneratif

Hasil Uji Organoleptik

(1) Hasil Penilaian Warna

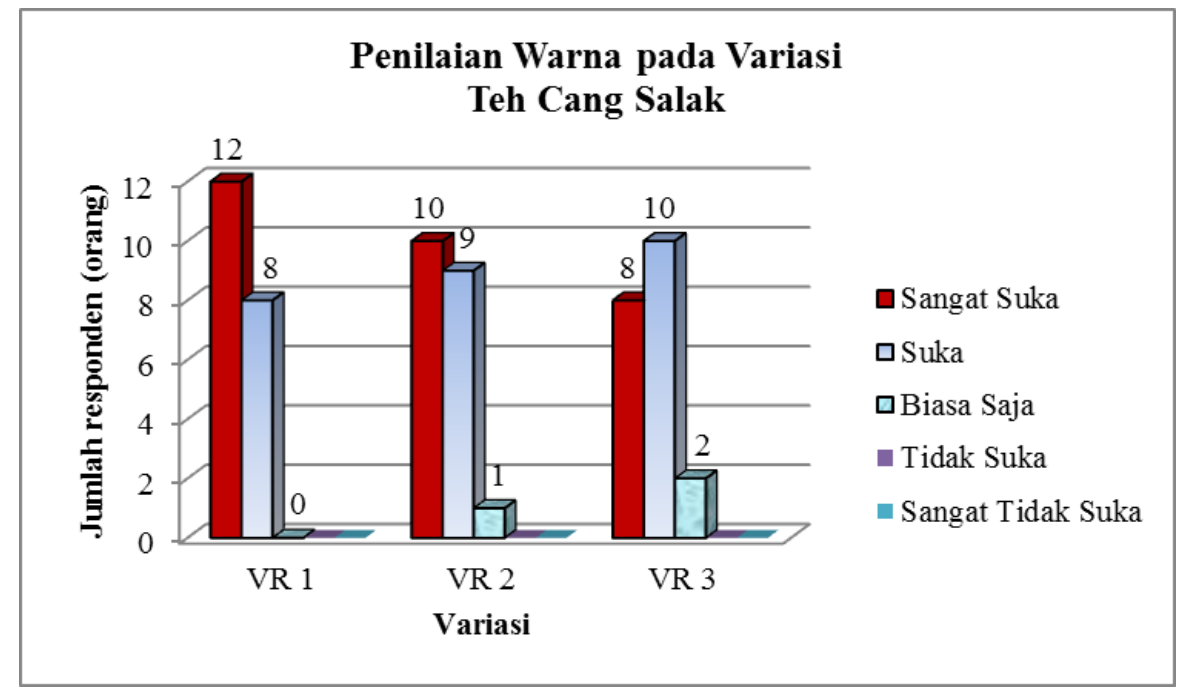

Gambar 1. Hasil Uji Penilaian Warna Teh Cang Salak

(2) Hasil Penilaian Rasa

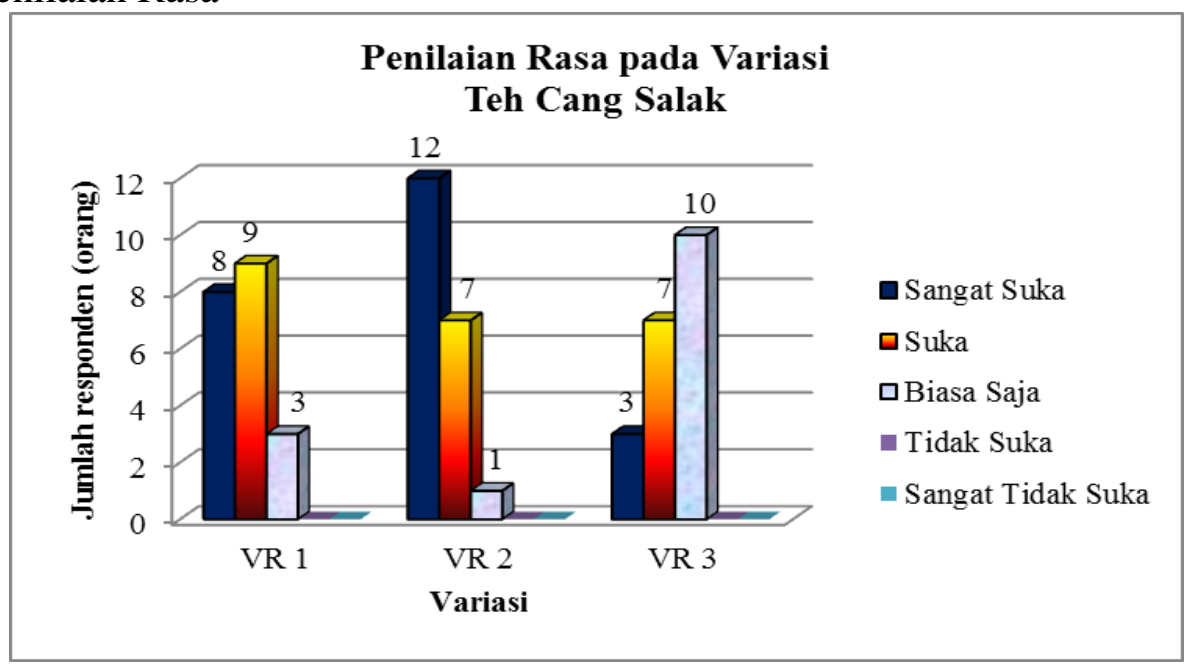

Gambar 2. Hasil Uji Penilaian Rasa Teh Cang Salak

Meditory | ISSN Online : 2549-1520, ISSN Cetak : 2338 - 1159, Vol. 7, No. 1, Juni 2019 
(3) Hasil Penilaian Aroma

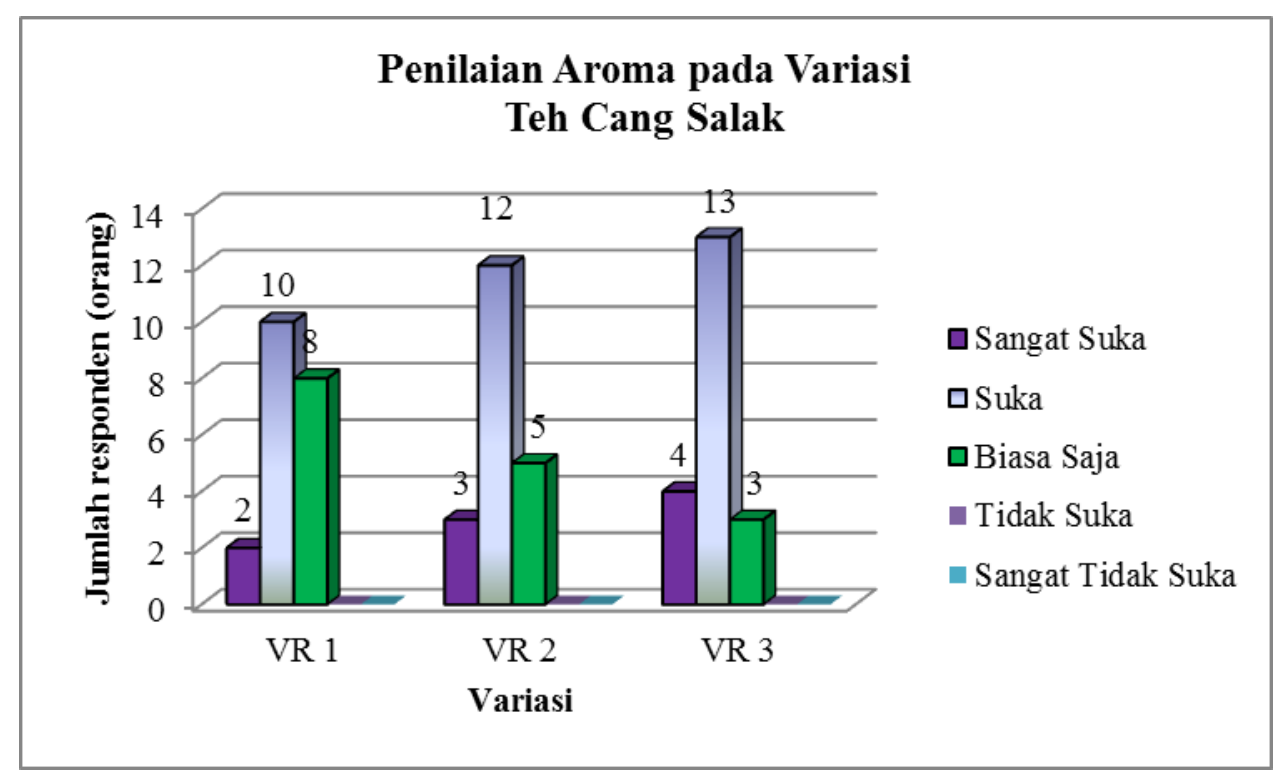

Gambar 3. Hasil Uji Penilaian Aroma Teh Cang Salak

Tabel 1 menunjukkan kandungan fitokimia yang terdapat pada masingmasing formula campuran. Ketiga formulasi menunjukkan adanya kandungan fitokimia yang sama. Hal in berarti kandungan aktif yang terdapat pada masing-masing sampel masih ada walaupun berbeda campuran. Masingmasing sampel mengandung adanya flavonoid, tannin, alkaloid, terpenoid dan persenyawaan fenol. Tabel 2 menunjukkan adanya perbedaan kadar antioksidan pada masing-masing formulasi sampel. Formulasi VR1 menunjukkan kadar antioksidan lebih tinggi, sedangkan VR3 memiliki kadar yang paling rendah. Hal ini terjadi karena kandungan antioksidan pada kayu secang lebih tinggi dibandingkan dengan kulit salak. Ekstrak kayu secang (Caesalpinia sappan L.) hasil penapisan mengandung lima senyawa aktif yang terkait dengan flavonoid baik sebagai antioksidan primer maupun antioksidan sekunder. Kulit salak lebih sedikit mengandung antioksidan tetapi memiliki metabolit sekunder lainnya yang berpotensi dalam pencegahan penyakit degeneratif. 
I Wayan Karta, dkk., Teh Cang Salak:Teh dari Limbah Kulit Salak dan Kayu Secang yang Berpotensi Untuk Pencegahan dan Pengobatan Penyakit Degeneratif

Ketiga formulasi memiliki kandungan flavonoid yang berpotensi dalam pencegahan penyakit degeneratif. Uji positif adanya flavonoid menunjukkan sampel memiliki aktivitas antioksidan. Antioksidan sangat bermanfaat untuk kesehatan. Antioksidan dapat menghentikan proses perusakan sel dengan cara memberikan elektron kepada radikal bebas. Antioksidan akan menetralisir radikal bebas sehingga tidak mempunyai kemampuan lagi mencuri elektron dari sel dan DNA. Mekanisme antioksidan dalam menghambat oksidasi atau menghentikan reaksi berantai pada radikal bebas dari lemak yang teroksidasi, dapat disebabkan oleh 4 (empat) macam mekanisme reaksi yaitu pelepasan hidrogen dari antioksidan, pelepasan elektron dari antioksidan, addisi asam lemak ke cincin aromatik pada antioksidan, serta pembentuk senyawa kompleks antara lemak dan cincin aromatik dari antioksidan $^{4}$.

Flavonoid dapat bekerja sebagai antioksidan untuk melindungi stres oksidatif sel. Mekanisme kerja flavonoid yang berhubungan pada efek penyakit yang dapat menimbulkan berbagai masalah kesehatan antara lain,
(1) Efek antiaterosklerosis. Sifat antioksidan flavonoid berpengaruh pada sistem vaskular. Radikal oksigen dapat mengoksidasi LDL, yang menyebabkan kerusakan dinding sel endotel dan berubah menjadi aterosklerosis, (2) Antiinflamasi. Siklooksigenase dan lipoksigenase memegang peran penting dalam mediator inflamasi. Oksidasi asam arakidonat yang melepaskan kedua zat tersebut dimulainya respon inflamasi. Neutropil.mengandung lipoksigenase yang menghasilkan senyawa kemotaktik dari asam arakidonat untuk melepaskan sitokin. Adanya senyawa fenolat dapat menghambat kedua jalur siklooksigenase dan lipoksigenase. Kuersetin menghambat aktivitas kedua jalur tersebut dengan cara menurunkan pembentukan metabolit inflamasi, (3) Efek antitumor. Efek anatitumor dari flavonoid masih diteliti. Sistem antioksidan yang tidak adekuat jumlahnya akan menyebabkan kerusakan sel dari radikal bebas. Oksigen reaktif dapat merusak DNA dan divisi sel dengan mengubah pasangan basa yang disebut dengan mutasi. Jika perubahan ini ditemukan dalam gen kritis seperti onkogen pada gen supresor tumor akan membentuk 
I Wayan Karta, dkk., Teh Cang Salak:Teh dari Limbah Kulit Salak dan Kayu Secang yang Berpotensi Untuk Pencegahan dan Pengobatan Penyakit Degeneratif

inisiasi atau progresif. Spesies oksigen reaktif (ROS) dapat bereaksi langsung pada gen sinyal dan pertumbuhan. Kerusakan sel akibat radikal bebas oksigen dapat menurunkan mitosis, menambah kerusakan DNA bentuk mutasi dan menambah paparan terhadap DNA ke mutagen. Flavonoid dapat menghambat karsinogenesis. Beberapa flavonoid seperti fisetin, apigenin dan luteolin adalah inhibitor poten dalam proliferasi sel, (4) Efek antitrombogenik. Flavonol adalah partikel antitrombogenik, karena partikel tersebut dapat langsung membersihkan radikal, dengan mempertahankan konsentrasi prostasiklin endotel dan nitrik oksida. Penelitian in vitro dan in vivo menunjukkan bahwa flavonoid merupakan bahan yang kuat untuk menghambat aktivitas jalur siklooksigenase dan lipoksigenase, (5) Efek Antivirus, dan (6) Efek antiosteoporosis ${ }^{5}$.

Adanya tannin, polifenol, alkaloid, dan terpenoid mendukung pemanfaatan produk Teh Cang Salak untuk antidiebetes. Mekanisme kerja berbagai tanaman yang mempunyai efek antidiabetes di antaranya adalah mempunyai kemampuan sebagai astringen yang dapat mempresipitasikan protein selaput lendir usus dan membentuk suatu lapisan yang melindungi usus, sehingga menghambat asupan glukosa dan laju peningkatan glukosa darah tidak terlalu tinggi, misalnya tannin. Kemudian mempercepat keluarnya glukosa dari sirkulasi, dengan cara mempercepat peredaran darah yang erat kaitannya dengan kerja jantung dan dengan cara mempercepat filtrasi dan ekskresi ginjal sehingga produksi urin meningkat, laju ekskresi glukosa melalui ginjal meningkat sehingga kadar glukosa dalam darah menurun dan mekanisme mempercepat keluarnya glukosa melalui peningkatan metabolisme atau memasukan ke dalam deposit lemak. Proses ini melibatkan pankreas untuk memproduksi insulin 6 . Selain beberapa mekanisme tersebut, terdapat mekanisme lain dalam hal mendukung penghambatan komplikasi pada penderita diabetes mellitus yaitu adanya antioksidan dan komponen senyawa polifenol yang menunjukkan dapat menangkap radikal bebas, mengurangi stres oksidatif, menurunkan ekspresi TNF- $\alpha$. Senyawa fitokimia ternyata mampu memanipulasi dengan berbagai mekanisme sehingga dapat mengurangi 
I Wayan Karta, dkk., Teh Cang Salak:Teh dari Limbah Kulit Salak dan Kayu Secang yang Berpotensi Untuk Pencegahan dan Pengobatan Penyakit Degeneratif

komplikasi diabetes melalui pengurangan stres oksidatif, ROS dan TNF- $\alpha^{7}$.

Metabolit sekunder dari kulit buah salak yang memungkinkan berpengaruh pada penurunan glukosa darah yaitu adanya tanin dan flavonoid. Dimana tannin bekerja sebagai astringen yang mempresipitasi protein pori-pori disaluran cerna dan mengurangi absorpsi glukosa serta kerja dari flavonoid yang bersifat antioksidan untuk mencegah stres oksidatif penyebab dari komplikasi penderita diabetes mellitus serta dapat pula membantu mensekresi insulin dari sel $\beta$ pankreas $^{8}$. Alkaloid terbukti mempunyai kemampuan regenerasi sel $\beta$-pankreas yang rusak. Alkaloid juga mampu memberi rangsangan pada saraf simpatik yang berefek pada peningkatan sekresi insulin. Kerja alkaloid dalam menurunkan gula darah dalam mekanisme ekstrak pankreatik yaitu dengan cara meningkatkan transportasi glukosa di dalam darah, menghambat absorpsi glukosa di usus, merangsang sintesis glikogen dan menghambat sintesis glukosa. Berdasarkan hal tersebut, teh Cang Salak memiliki potensi untuk pencegahan dan penatalaksanaan penyakit degeneratif akibat adanya radikal bebas, seperti diabetes mellitus.

Berdasarkan pada uji organoleptik menunjukkan diterimanya produk oleh para panelis Gambar 1, Gambar 2, dan Gambar 3. Secara umum menyatakan akan kesukaan akan produk ketiga varian tersebut. Dari ketiganya, VR1 lebih disukai dari segi warnanya, sedangkan aromanya lebih banyak pada VR3, dan rasanya pada VR2. Warna yang menarik ditimbulkan oleh adanya kayu secang lebih banyak pada VR1 yang banyak mengandung senyawa brazilin. Kemudian aroma lebih muncul dengan adanya penambahan kulit salak. Untuk ke depannya perlu dilakukan penelitian lebih lanjut mengenai kekuatan antioksidan dan pengujian lebih lanjut tentang sejauh mana teh Cang Salak bisa digunakan antioksidan.

\section{SIMPULAN}

Berdasarkan hasil penelitian dan pembahasan dapat disimpulkan dalam penelitian sebagai berikut: (1) Teh Cang Salak memiliki kandungan aktif fitokimia flavonoid, tannin, alkaloid, terpenoid, dan fenol pada ketiga variasi. (2) Kapasitas antioksidan tertinggi ditemukan pada VR1 yaitu 343,88 mg/L GAEAC. Perbedaan kandungan tersebut diakibatkan oleh adanya antioksidan 
I Wayan Karta, dkk., Teh Cang Salak:Teh dari Limbah Kulit Salak dan Kayu Secang yang Berpotensi Untuk Pencegahan dan Pengobatan Penyakit Degeneratif

pada kayu secang lebih tinggi dibandingkan dengan kulit salak. (3) Uji organoleptik menunjukkan produk teh Cang Salak yang paling disukai adalah pada VR1, aromanya pada VR3, dan rasanya pada VR2.

\section{Daftar Pustaka}

1. Azzamy. 2015. 4 Jenis Teh Terpopuler dan Manfaatnya. Diakses pada http://mitalom.com/4-jenis-tehterpopuler-dan-manfaatnya/, diakses tanggal 7 September 2018

2. Fitrianingsih S.P., F. Lestari, S. Aminah. 2014. Uji Efek Antioksidan Ekstrak Etanol Kulit Buah Salak [Salacca Zalacca (Gaertner) Voss] Dengan Metode Peredaman DPPH. Prosiding SNaPP2014 Sains, Teknologi, dan Kesehatan ISSN 2089-3582

\section{BPOM.RI 2008 Caesalpinia}

sappan. Direktorat Obat Asli Indonesia.

4. Sayuti, K., R. Yenrina. 2015. Antioksidan, Alami dan Sintetik. Padang: Andalas University Press

5. Prasain, J.K., S.H.Carlson, J.M. Wyss. 2010. Flavonoids and Age Related Disease: Risk, benefits and critical. Maturitas. 2010 June ; 66(2): 163-171. doi:10.1016/j.maturitas.2010.01. 010.

6. Widowati, W., 2008, Potensi Antioksidan sebagai Antidiabetes, JKM, 7:2, 1-11.

7. Tiwari, A. K. and J. M. Rao, 2002, Diabetes mellitus and multiple therapeutic approaches of phytochemicals: Present status and future prospect, Current Science, vol 83, 1 (3038).

8. Suarsana, I. I., 2009, Aktivitas Hipoglikemik dan Anti Oksidatif Ekstrak metanol Tempe pada Tikus Diabetes, Institut Pertanian Bogor, Bogor. 